\title{
The Argentina Paradox: microexplanations and macropuzzles
}

\author{
Alan M. Taylor ${ }^{1}$
}

Received: 8 September 2017/Revised: 15 September 2017/ Accepted: 11 October 2017

(C) The Author(s) 2017. This article is an open access publication

\begin{abstract}
The economic history of Argentina presents one of the most dramatic examples of divergence in the modern era. What happened and why? This paper reviews the wide range of competing explanations in the literature and argues that, setting aside deeper social and political determinants, the various economic mechanisms in play defy the idea of a monocausal explanation.
\end{abstract}

Keywords Latin America · Growth · Trade · Finance · Institutions · Policies · Divergence

JEL Classification $\mathrm{F} 43 \cdot \mathrm{N} 16 \cdot \mathrm{O} 11 \cdot \mathrm{O} 54 \cdot \mathrm{O} 57 \cdot \mathrm{P} 52$

\section{Introduction}

There is an old saying among economists, possibly apocryphal, and of unclear attribution: "throughout history there have been only four kinds of economies in the world: advanced, developing, Japan, and Argentina".

This idea can be more concretely grasped by looking at evidence on the long run levels of income per capita in a broad range of countries over the last two centuries in Fig. 1. Material living standards have advanced across the entire world, but the

Prepared for the conference "Exceptional Argentina" at Harvard University organized by Rafael Di Tella, Edward Glaeser, and Lucas Llach. I thank the organizers/editors, anonymous referees, and conference participants for useful comments and suggestions on this paper. All errors are mine.

Alan M. Taylor

amtaylor@ucdavis.edu

1 University of California, Davis, USA 


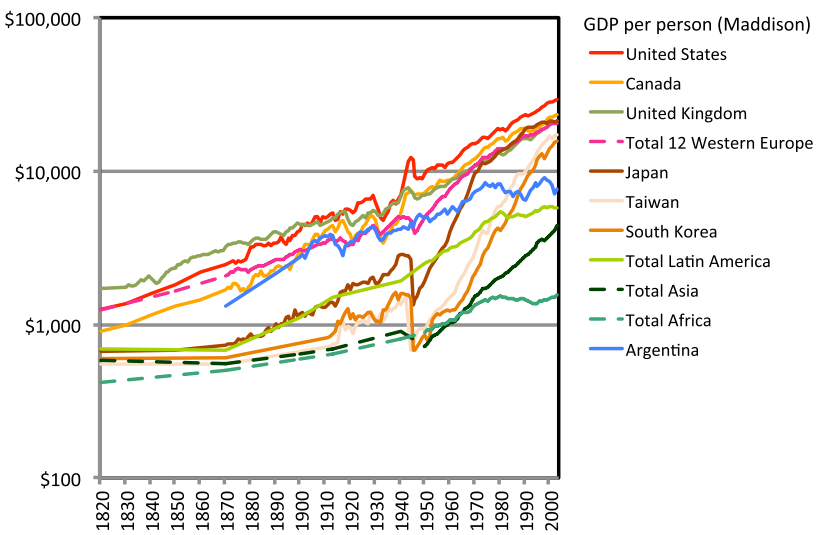

Fig. 1 The great divergence and Argentina. Source: Maddison (2007)

well-known Great Divergence is quite apparent. A few rich countries have become much richer; a larger group of poorer countries have grown more slowly average. Within each group are notable exceptions, with some very poor countries making little progress at all. However, most striking is those countries witnessing a reversal of fortune, moving from one group to the other.

The set of once-poor countries that are now rich include Japan, where the transition began more than 100 years ago, and some other East Asian countries such as Korea and Taiwan, whose transition started only 50 years ago and is now almost complete. But going the other way there is only one notable case of a country that started life relatively rich and ended up comparatively poor: this is the great puzzle or paradox of Argentina. In the late nineteenth century, it was among the top five countries in income per capita, richer than all European countries except Britain and on a par with other rich settler societies such as the United States, Canada, and Australia. Its status among the richest economies reached a peak around 1913 when income convergence stopped. But even until 1929 it still clung on in this club, only to face a slow and widening relative decline thereafter. It is now close to the average country in the world given its level of income per capita, and its citizens enjoy only $40 \%$ of the average income per capita of the 12 core countries of Western Europe.

\section{1 "MicroExplanations": trade and investment}

In a complementary chapter by Lucas Llach in this volume, written with a different focus, some important background is developed for the topics explored here. Llach discusses how the prosperity of Argentina in the circa 1913-1929 period was potentially fragile and thus vulnerable to reversal: the pre-1914 boom had been narrowly built on the physical capital of railways and the cereal lands of the pampas they made viable, but the potential for broader growth via industrial and human capital was constrained. On wider human development measures, including schooling and health, Argentina lagged its rich country rivals, and on a regional basis its wealth was heavily concentrated in the city of Buenos Aires and its 
surrounding province. Such were the peculiar initial economic conditions in Argentina circa 1929.

To complement those findings, this chapter looks elsewhere, and in two different directions: it looks back to some of the theories of historical "deep determinants" and how they might relate to Argentina's malaise; and it steps forward to look at the evolving story after the Great Depression with these initial conditions kept in mind. I explore some of the main contours of the Argentina "macropuzzle" as the great divergence in per capita incomes emerged and then widened after 1929, and look at some of the quantitative explanations that have been advanced for it, in particular, the central roles played by barriers to trade and investment.

There are many of these (and other) distortions in Argentina-perhaps too many for the tastes of economists easily seduced by monocausal explanations tied to a toy model with a minimum of parameters. But we are in a country with an untidy economic history: in economic policy terms, it is a place where almost anything that could go wrong has, at some time, actually gone wrong. In this weirdest of historical laboratories, dozens of strange economic policy experiments have been run in the last 200 years, often for long periods, and not infrequently with lasting consequences. Still, in sum, a focus on some key "microexplanations" can help us to understand a lot of what went wrong at the nexus of public policy and economic performance.

\section{2 "Macropuzzles": elusive deep determinants?}

Yet beyond the search for immediate causes, of equal or greater concern to some economists has been the search for so-called "deep determinants" of economic outcomes, consisting of causally_and often temporally_distant factors that might be placed as primal or exogenous factors which "explain" the proximate cause and, hence, the ultimate outcome of economic underperformance. Among the most widely cited explanations are a country's geography (including land/resource endowments as well as climate/disease environment), its colonial experience, and the origins of its legal system.

We shall review each of these explanations as applied to the Argentine case, and find that, in contrast to many other countries, most of these explanations do not fit all that well. For example, Argentina is a predominantly temperate country, it has been dominated by European settlement, it has maintained high literacy despite the inequality, and its legal origins are a peculiar hybrid of common and civil law ideas. Thus, in the debate over the causes of economic success and failure, Argentina stands as an exception to many of the rules which seem to apply elsewhere, deepening the mystery.

This contrast leaves us with the "macropuzzles": we have much work left to do to piece together a plausible story not only of what went wrong, but why it went wrong. What were the political economy mechanisms that derailed Argentina in the twentieth century? A century ago, despite some bumps in the road, the country was prosperous and literate, in a temperate zone, economically open, had reasonably tolerable rule of law, and was progressing towards macroeconomic stability and a 
liberal constitutional democracy. It was not so unlike the other settler countries. Today, a century later, it looks very different.

\subsection{The explicandum}

In the two main sections of the paper that follow we look at some commonly discussed proximate factors behind Argentina's relative economic decline. We attempt to put these factors in some kind of empirical perspective and evaluate how much they might have contributed to Argentina's economic slow down.

To do so we will be primarily concerned with the steady-state impact of such effects on output. In all cases, the exact levels of these distortions have varied substantially over time, but given the slow convergence to steady state in any benchmark neoclassical model (empirically or theoretically), these factors will have a high degree of historical persistence across years and decades in any calibrated dynamic model.

With the strong forces of inertia noted, it is worth keeping in mind the kind of income gaps we have to explain. The income per person level in Argentina today (about \$8000) is about two-fifths of that in the rich world Western Europe (about $\$ 20,000)$. Thus, we are looking for a factor, or set of factors, that when imposed on a rich country can cause income to fall by a factor of $2 / 5$ (or drop 60\%); or equivalently, factors which when removed from a poor economy could cause incomes to rise by a factor of $5 / 2$ (or increase by $150 \%$ ). Or, perhaps more cleanly, in log terms we seek to explain a change in relative income of just under $1.000 \mathrm{log}$ points.

\section{Argentine trade in the twentieth century}

For most of the twentieth century, Argentina's trade volumes (as a fraction of GDP) have been very low, whether relative to their initial levels in the 1900-14 period, or relative to the trade levels one might predict in a similar economy of comparable size and geographic remoteness.

Figure 2 traces the evolution of the trade share over time in Argentina, measured by exports plus imports divided by GDP. From a high of $80 \%$ or more on the eve of World War One, this ratio fell to levels below 20\% in the 1920s and 1930s and has remained there ever since (Berlinski 2003). Even with the push towards liberalization in the 1990 s this ratio barely ticked up during that decade. This pattern constitutes the main empirical fact about trade in Argentina in the twentieth century.

One question is how much of this trend is explicable in terms of (potentially changeable) trade policy frictions? And importantly, in addition, how much of those frictions reflected policies in Argentina as compared to the Rest of the World? From the 1930 s to the 1960 s, trade barriers were high almost everywhere in the global economy. As Díaz Alejandro and others have noted, Argentina's policy decisions were, therefore, not that unusual, and, as in many other countries, the shift towards import substitution industrialization (ISI) was a reflection of path dependence and 


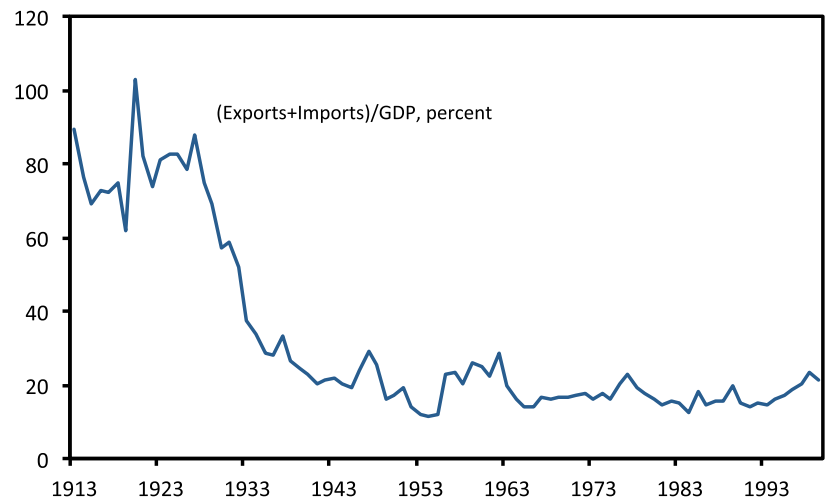

Fig. 2 Trade volumes. Source: Berlinski (2003)

political economy dynamics: when the world's rich, core economies chose autarky in the 1920s and especially 1930s - forces then amplified by wartime frictions - the countries of the periphery had to seek another economic strategy in the short term, and having been exposed to the downside risks of openness and specialization in the primary-product "lottery," they were understandably wary of again placing large bets predicated on the assumption of a stable, globalized, liberal world order with open markets for trade. Argentina fits this pattern.

However, while Argentina's stance was not that peculiar by the standard of developing countries, where inward-looking development strategies were the norm, it was unusual by the standard of the rich countries, the club to which ostensibly Argentina wished to belong, or rather remain. After 1945, the gradual progress of GATT (and in Europe of the EU project after 1957) carried trade integration rapidly forward. But until the Uruguay Round (circa 1990) of negotiations, Argentina, like most other developing countries, stood apart from this process, and policies remained strongly protectionist.

Data on the distortionary impact of quotas are scant, but these barriers were often very significant in the Argentine context, whether imposed directly or by the quota rationing of foreign exchange (as in the 1940s and early 1950s). Trade taxes are easier to document, and Fig. 3 shows what we know about average import and export taxes in the long run (Berlinski 2003). Import taxes were not trivial prior to World War One as they were a key revenue source, but export taxes were zero. Subsequently, in the 1920s and 1930s, average trade taxes began to climb. They abated during World War 2 and the early postwar exchange control epoch. Then import and export taxes climbed rapidly after 1960, to about a $15 \%$ level for each, or a $30 \%$ distortion total. Judging from the timing of two asymmetrical spikes in the 1980s, export taxes tended to evaporate in hyperinflation episodes, while import taxes tended to rise in an offsetting fashion, but these figures may also reflect accounting problems. In the liberalization period of the 1990s, export taxes were lifted, but import taxes remained high, although trade policy becomes somewhat more liberal on other dimensions (e.g., quota removals for GATT/WTO compliance and an attempt to start a regional trade area, MERCOSUR). 


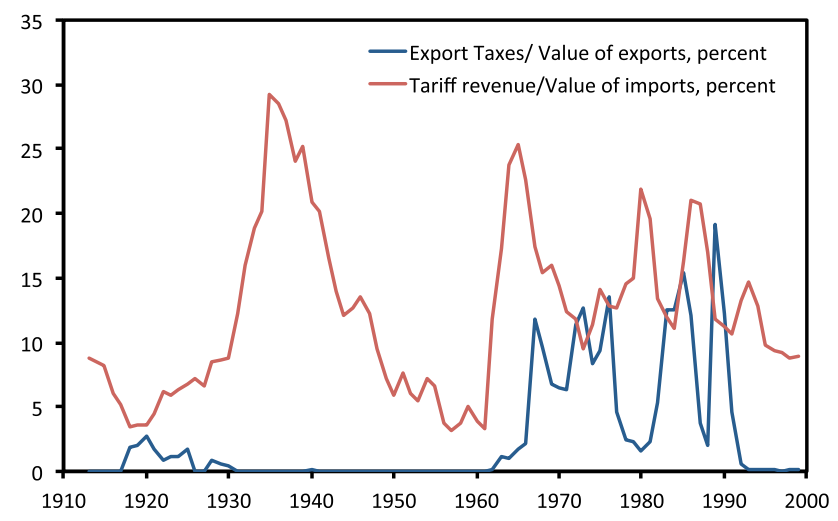

Fig. 3 Trade taxes. Source: Berlinski (2003)

What would be the likely impact of these trade barriers on income levels? We cannot hazard a precise answer but we can use some simple impacts based on either calibrated models or econometric estimates. In this setting, I will neglect the standard dead-weight loss considerations since utility losses arising from static consumption and production distortions are typically an order of magnitude too small to be useful in discussions of the Great Divergence (usually 1-2\% at most). I narrow the focus further by examining the impact of trade frictions on two of the most widely discussed channels through which protectionist policies might lower incomes.

First, higher trade costs raise the costs of imported capital goods and intermediate inputs. These costs are nontrivial, and they matter all the more in countries that are both very open and have comparative disadvantage in these products. Argentina is a classic example of such a country, and the understanding of this type of drag on economic performance dates back to the classic analysis of postwar underperformance by Díaz-Alejandro (1970), who noted that many key imported capital inputs (e.g., farm or industrial machinery) bore domestic prices that were very high indeed compared to world prices.

Let us now feed some numbers into a model, backed by econometric support, that can capture this effect. Suppose, as noted above, trade costs increase by $50 \%$ due to trade barriers (the rough magnitude of the trade tax burden since 1950). Also suppose that imports in the initially open economy would be $40 \%$ of GDP (the figure last seen in Argentina circa 1910, the last date when both it and the rest of the world were close to fully open). Let us assume that intermediate inputs account for $50 \%$ of imports, and capital goods account for $25 \%$ the roughly stable figures seen in decades of historical data in Argentina (Berlinski 2003).

Using the Estevadeordal and Taylor (2013) standard open-economy neoclassical model, we could conclude that the trade taxes would lower GDP by roughly 0.200 $\log$ points or $20 \%$ in the long run steady state, given the import shares as above. Two-thirds of this would arise due to higher costs of intermediates (an effect analogous to a negative productivity shock) and one-third would arise from the higher cost of capital goods (an effect analogous to a negative savings rate shock). 
These are quantitatively large effects when the full gap to be explained is $1.000 \mathrm{log}$ points, since they explain one-fifth of Argentina's decline.

A further place to look for an impact of trade frictions on output is in the process of technology transfer. Here there are plenty of candidate theoretical models, but no consensus on the structure and calibration that best fits the data, nor is there solid statistical evidence for this channel. Accordingly let us rely on recent empirical estimates and, since the effects will turn out to be small anyway, allow ourselves to compute an upper bound for this effect. In recent work, Acharya and Keller (2008) examine the impact of expanded imports from the "technology leader" country on the TFP levels in follower countries, controlling for import levels and R\&D intensity in the leader, and interactions between the two. For their analysis, based on mostly developed countries, and the US is the leader.

Here, we consider how the same analysis might apply to Argentina as a follower, where the OECD might serve as the R\&D source. One of the upper bound results in Acharya and Keller (2008, Table 8) suggests that a "high" estimate (the 95th percentile) for the elasticity of local TFP with respect to import volume is about 0.06 for the case of R\&D intensive sectors. (For many sectors the effect is small or negative, reflecting the possibility of countervailing forces where, say, import competition is destructive of an industry that cannot catch up.)

Applying these estimates, if we apply the 0.06 elasticity to the post-1914 halving of Argentina's trade volumes, then this implies a reduction of TFP due to weaker technology transfer of about only 3\%. In steady state, given endogenous capital accumulation, the impact on income would be somewhat larger and might account for an overall income effect of $5 \%$ or just $0.050 \log$ points. So technology transfer via imports would appear to be a very small part of the overall story: the statistical evidence for the channel is quite weak in aggregate, even if we make several calibration assumptions designed to make its impact as large as we dare. To sum up, in contrast to income losses due to inhibited technology transfer (about $-5 \%$ or $-0.05 \mathrm{log}$ points of income) the bulk of the income losses due to trade policy frictions (about $-20 \%$ or $-0.200 \log$ points of income) would seem to derive from the direct effect of increased input costs for capital and intermediates.

\section{Argentine investment in the twentieth century}

A second area we might examine as an explanation for Argentina's low income is capital scarcity. By this we mean, in a standard neoclassical growth model, a suboptimal capital/labor ratio, denoted $k=\mathrm{K} / \mathrm{L}$. In the simplest model, output per worker $y=\mathrm{Y} / \mathrm{L}$ is expressed as $y=A k^{a}$, where A is productivity (total factor productivity or TFP) and a capital share of $a=1 / 3$ is the typical exponent used in modern empirical work (Gollin 2002).

The steady state of the model, at a per worker capital level $k^{*}$ and output level $y^{*}$, can be solved by assumptions on capital accumulation, typically by either using a Solow or Ramsey growth model. In either of these models $k^{*}$ and $y^{*}$ rise endogenously in response to an increase in TFP, or A. Thus, in a "levels accounting" exercise, a country's income level (relative to some reference country, 
0 ) can be broken down into (1) a shortfall in TFP, that is $A$ below $A_{0}$; and (2) a friction preventing $\mathrm{k}$ from reaching it hypothetical optimal level $k^{*}$, due to investment taxes or other distortions that create a wedge and keep the marginal product of capital MPK above its optimal level MPK*. Since the production function is Cobb-Douglas, $\mathrm{MPK}=\mathrm{a} \times \mathrm{APK}$ is proportional to $\mathrm{APK}=\mathrm{Y} / \mathrm{K}$; hence, these deviations can be written, following Hall and Jones (1999) as:

$$
y / y_{0}=\left[A / A_{0}\right] \cdot\left(\mathrm{MPK}_{0} / \mathrm{MPK}\right)^{[a /(1-a)]},
$$

where, by proportionality, $\mathrm{K} / \mathrm{Y}$ is replaced with a/MPK, additional human capital terms are omitted for simplicity, and where the exponent in this equation is $1 / 2$, given that $a=1 / 3$.

As regards the Great Divergence in incomes between rich and poor countries, the consensus since Hall and Jones, has been that the $A / A_{0}$ term above explains much more of the divergence than the $\mathrm{MPK} / \mathrm{MPK}_{0}$ term (e.g., see Easterly and Levine 2001; Gourinchas and Jeanne 2006; Caselli and Feyrer 2007, inter alia). Indeed, for Argentina, Hall and Jones used 1988 data to compute that the MPK term above explained about $5 \%$ of the income difference between Argentina the United States. Does this mean that the MPK explanation is dead?

Not quite. Ideas from recent empirical research can provide us with an improved understanding of the evolution of the Argentine capital stock. Properly computed, MPK distortions make a significant contribution to the income gap. For example, Fig. 4 plots the implied MPK for the United States and Argentina using the HallJones method based on installed capital derived from a perpetual inventory method (PIM). Their estimates stopped in 1988 since that was the last year of PWT 5.6, their data source. But we now have PWT 6.2, with coverage until 2004, and we can see that 1988 was quite an unusual year.

Argentina had over-borrowed and over-invested prior to the debt crisis, and then in 1988-90 output was depressed as the economy slumped into recession and

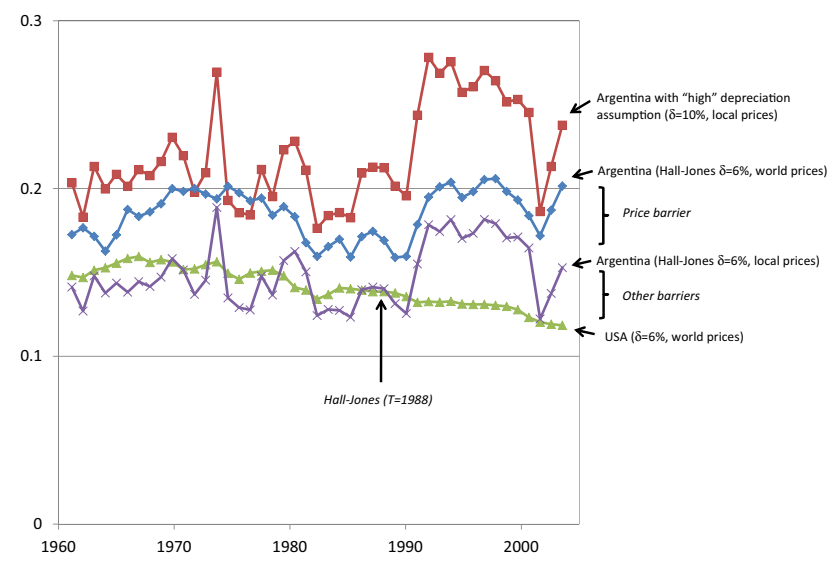

Fig. 4 The marginal product of capital. Source: Author's calculations based on the method in Hall and Jones (1999) extended from 1960 to 2005 using Penn World Table 6.2 data 
hyperinflation, with installed capital suffering heavy underutilization. If one wanted to pick a moment to make Argentina's APK, and hence MPK look as low as possible, that would have been the year to choose, suggesting a small MPK distortion in total, and none at all after a price adjustment, and hence minor capital scarcity problems. Mismeasurement is, therefore, a potentially serious issue for this calculation.

And as we can see, for most of the last three decades the story has been very different. Using data back to 1960 and the Hall-Jones PIM standardized depreciation rate of $6 \%$, the Argentine MPK level appears to be on average $50 \%$ higher than the US level, a considerable wedge. I would argue that the deviations from this pattern in the 1980s and in 2000-03 are easily understood and should be discounted: these were periods of severe economic downturn when measured installed capital is not the same as capital in use. Were it possible to further refine Argentina's measured capital input time series every year for capacity utilization levels-something no statistician has yet done-we would probably discover similar gaps even in the recession periods.

Are these wedges entirely due to a factor we have already considered, the relative price of capital? If so, we must not double count, which necessitates evaluating MPK at local rather than world prices. The chart shows that this does make a small difference. Evaluated at local prices the gap is clearly not so large, but it is still significant, and it matches up with other recent capital stock estimates using different methodologies. For example, Coremberg (2003) pegs the Argentine and US capital-output ratios in 1998 at 2.85 versus 1.95 , respectively, translating into APK levels of 0.351 versus 0.513 , and in turn (assuming $a=1 / 3$ ) MPK levels of 0.117 and 0.171 .

These independent country-specific estimates very closely match the rough estimates in Fig. 1 after applying the domestic price correction (where the 1998 MPK levels are 0.129 and 0.180). These gaps have factored in the trade distortions considered above: these are, in other words, evidence of additional capital wedges, beyond barriers to trade in capital goods. And they still show MPK 50\% higher in Argentina than in the United States.

These data push back a little against the "it's A not k" line of argument commonly applied to developing country underperformance. Even researchers working in traditions traditionally sympathetic to TFP-based explanations have had to concede that the large MPK gaps in the 1990s are clear evidence of "capital shallowing" in Argentina. That is, even in the most dramatic period of economic success in recent years, there was a pronounced failure of capital accumulation to keep pace with the path one might expect during a productivity boom (Kydland and Zarazaga 2002). These findings suggest that Argentina does have some difficulty in mobilizing adequate capital accumulation, even when profitable conditions appear. Perhaps from the 1960s to the 1980s slow investment was the counterpart of decelerating productivity, and Argentina could coast along with a depreciating capital base and modest net capital stock additions, but then in the 1990s, the scope for TFP led growth appeared and capital was apparently not adequately mobilized.

The income implications of these gaps are nontrivial. Suppose MPK in Argentina is, on average, $50 \%$ or $0.500 \log$ points above the US level as is suggested in the 
above estimates from the 1990s, from either the PWT or Coremberg. Then in the above expression for income differences, applying the exponent of $1 / 2$, this capital accumulation friction or wedge explains $25 \%$ or $0.250 \mathrm{log}$ points of the overall income difference between the two countries, and we have explained another onequarter of the Argentine puzzle.

If capital is low, and MPK is high, compared to the neoclassical benchmark, this begs the question: why has Argentina under-invested to such an extent that the marginal product of capital has found itself, so often, stuck far above reference levels? What is the nature of the investment wedge? What underlying factors cause this distortion? I cannot quantify every possible channel, but I propose several candidate explanations which center on factors that either raise the cost of capital or the risk of investment, and all may warrant further scrutiny.

First, there is the problem of risk due to macroeconomic rare events. As is well known, returns to risky investments often appear excessive given what seem like plausible models of risk aversion (Mehra and Prescott 1985). However, the possibility of rare "crash" states or valuation jumps, which wipe out significant wealth through large capital losses, may well be sufficient to resolve this puzzle (Rietz 1988; Barro 2005). And undoubtedly, Argentine history is filled with many examples of crashes that severely damaged many kinds of investment returns. High or hyperinflation events eroded nominal debts on several occasions. These and other major economic crises have often left the banking sector in ruins, causing credit crunches and broader losses on a wide range of financial instruments. If, as a result, investment returns are more crash prone in Argentina then investors may demand a higher return as compensation for volatility and/or skew, implying a higher equilibrium MPK in aggregate. These risks may also be manifest in a repressed financial system with lower money multipliers and leverage, further tightening credit.

Second, there is the problem of default risk and property rights. In addition to rare events driven by market fluctuations, possibly in response to macroeconomic policies, we also have to recognize that explicit confiscation or redistributions of wealth, or other failures of property rights, have often figured in Argentina's history. Beyond the serial pattern of default (Reinhart and Rogoff 2004), we would include bank suspensions, forced debt conversions, specifications, and other expropriations. Although on occasion, ex post, these events were discriminatory as to locals versus foreigners, on most occasions, and in general ex ante, such differential treatment may not have been expected.

If capital price distortions (e.g., trade policy) explain $0.250 \mathrm{log}$ points of income difference, and capital accumulation frictions (high MPK) explain another $0.250 \mathrm{log}$ points, we have explained one half of the $1.000 \mathrm{log}$ point income difference. This is not trivial. A 50\% increase in income per person would lift Argentina from the $\$ 8000$ level to the $\$ 13,000$ level (roughly on a par with Greece, Portugal, and approaching South Korea). And even in 1913, at its relative peak, Argentina's income was at most 70-80\% of US or UK levels, so were even half of today's gap closed like this we would probably not speak so much of an Argentine puzzle. 
Still, can we explain any more of the OECD-Argentina gap? There is a reason to think that we can, for various reasons, given several empirically important factors we have not yet accounted for. Three such factors could be very important.

First, there is the issue of investment quality. All calculations of MPK rely on calculations of capital stocks based on PIM or HV methods and many standardized assumptions. But capital "quality" may be generally lower in poorer countries. Public investments are often more dilapidated in poor countries with low quality of governance, and where large fractions of public investment spending are lost to bribery and corruption (Tanzi and Davoodi 1997). Firm data from some countries suggest that the same may be true of private sector investments ( $\mathrm{Bu} 2006)$, perhaps due to private sector corruption; or due to high costs or barriers to technical maintenance; or due to capital complementarities with adversely maintained public capital, leading to premature discard or under maintenance. Capital is thus less productive and of lower capacity than its vintage alone would suggest and some correction for higher rates of depreciation is warranted. For example, the Hall-Jones method assumes a $6 \%$ depreciation rate on all capital. But these rates may be far too low for uniform application to rich and poor countries. Bu (2006) estimates "low" median firm depreciation rates for all fixed assets as $16 \%$ (Philippines) or $12 \%$ (South Korea) in the 1990s. In Indonesia and some African countries, the reported median depreciation rates are higher still, between 25 and $60 \%$. This poses a profound problem for capital stock and MPK estimates because the results are highly sensitive to the depreciation parameter: increase this parameter by $1 \%$ and the implied PIM measure of the capital stock falls by $1 \%$, and implied MPK rises by $0.67 \%$ (if $a=1 / 3$ ). If capital quality is lower and depreciation higher than typically assumed, Argentina could be even more capital scarce than has been commonly thought.

Second, there is the problem of investment misallocation. The MPK calculations also rely on the assumption that capital is efficiently allocated within the economy, or that MPK is equalized across sectors. But a contrary view with a log tradition maintains that this is unlikely to be the case in developing countries. Instead, investment may be misallocated for a variety of reasons-such as corruption and inefficiency in the private financial sector or the role of the state in allocating finance. Work by Hsieh and Klenow (2009) on China and India suggests that, compared to the US, an efficient re-allocation of capital could be the equivalent of a $50 \%$ or larger increase in TFP. It is quite plausible that similar misallocation problems, although perhaps not as grave, could affect Argentina and would go along way to explaining any remaining income gaps, over and above what we have measured so far. This is likely to be a productive area for future research, using industrial census data and other measurements.

Third, and finally, there is the role of investment variety. Input price distortions were probably the main trade-related drag on Argentina's growth in the twentieth century. After 1914, and particularly from the 1930s to the 1950s, this scenario could be ascribed in some large part to highly unfavorable global conditions for open trade; but once global trade started to boom thereafter, self-inflicted trade policy distortions would remain as the principal cause of the problem. The estimate presented above ( $0.200 \log$ income points) may also be an understatement since it 
focuses only on the so-called "intensive margin" - the quantity of a given set of goods imported. But recent empirical research in the trade literature suggests that comparable economic costs may be inflicted by input tariffs on the "extensive margin"-by limiting the variety of inputs that are imported. If these results carry over to intermediate and capital inputs, as they well might, then we would have identified yet another trade-related barrier to investment. Quantifying that impact for a broad range of countries, as well as for Argentina itself, remains an important goal of future research.

These three additional factors - investment quality, allocation, and varietyrepresent additional barriers to efficient investment which have also probably acted as a drag on Argentine economic performance, even if the magnitudes in question remain open frontiers for research.

\section{Concluding thoughts: deep determinants}

The discussion so far of likely "microexplanations" suggests that we know, within some approximate bounds, how various economic policies and institutional deficiencies in the Argentine economic environment might have contributed to economic underperformance. And indeed these contributions appear to be empirically large, sufficient to explain much of the divergence witnessed. But this only pushes the question deeper: why have such choices been made and what can account for them?

For all countries, not just Argentina, economists and historians have grappled with this question in a bid to explain the deep and exogenous origins of the Great Divergence. The problem, as I argue in this section of the paper, is that in the particular case of Argentina the explanations that have been proposed-and which may seem to work quite convincingly in many other countries-do not appear half as persuasive when applied to Argentine economic history.

\subsection{Geography and empire}

To set the stage let us consider a now conventional casual ordering in the levels accounting literature. As above we claim that policies causally affect outcomes, which we might write as "policies $\rightarrow$ income per person" in simple notation. A problem that concerns some scholars is the potential for reverse causality from incomes to policies, suggesting we look for deeper determinants that explain policies. For example:

$$
X \rightarrow \text { policies } \rightarrow \text { income per person. }
$$

If $X$ is an exogenous deep determinant, it may then be brandished as an instrumental variable to avert endogeneity problems when regressing incomes on either policies or institutions (e.g., see Acemogluet al. 2001; Rodrik et al. 2004).

Candidates for $\mathrm{X}$ are numerous in the literature. Geographic determinists have focused on latitude, or climate/crops, or disease endowments. Disease may have 
direct effects on labor productivity (Gallup et al. 1999). Crops may affect production organization and subsequent institutions, such as slavery, and hence the path to democracy and capitalism (Engerman and Sokoloff 1997; Easterly and Levine 2003). Alternatively, the impact of disease and climate may have been more indirect, with European colonists less (more) likely to settle in the tropical (temperate) regions, and more (less) likely to construct "extractive" institutions there (Acemoglu et al. 2001).

In those accounts where historical institutional choices matter (Engerman and Sokoloff 1997; Acemoglu et al. 2001), the key to a present-day impact is via a political economy persistence mechanism, whereby even after independence a high level of inequality preserves colonial extractive institutions, favoring elites, and leading to high inequality in incomes and education, and persistently low levels of economic development.

It now starts to become apparent why some of these theories may be poorly equipped to explain the case of Argentina. Argentina is essentially in a temperate zone, not a tropical zone, and that is especially true of the economic heart of the country - the pampas and littoral regions. Those regions are also populated by a stock of people of European descent, and they are physically and culturally separate from the country's colonial centers in the altiplano. Slavery existed, but was brief and localized. Most importantly, the country did not endure persistent underdevelopment: whatever its physical and political legacy at independence, by 1900 this was a rich country, a functioning democracy with expanding suffrage, and most importantly an economy equipped with a decent schooling system and, for its time, creditable levels of human capital (see the chapters by Llach and Campante and Glaeser for more discussion on the role of education and human capital).

Argentina resembled Canada more than Cameroon in 1900. The problem to be explained is not that the country never developed-but that it had the potential for success, at one time it lived up to it, and then found ways to fall back into underdevelopment. It is, by construction, very difficult for geographic and historical "deep determinants" to explain this kind of reversal when they rely on persistence of institutions, inequality, and economic backwardness over time. And, by way of more direct refutation, a micro-level study of the proposed inequality-based transmission mechanism raises further doubts: recent research has shown that inequality was not purely a legacy of the colonial period (Arroyo Abad 2008): in fact from 1820 to 1914 , many countries saw inequality rise and fall more due to external shocks (terms of trade, migration), and the inequality at independence thus turned out to be a poor predictor of their inequality in 1914 .

One way out of this conundrum is to keep the focus on exogenous factors, but to look either at alternative deep determinants (e.g., law) or else at the interaction of historical initial conditions with the powerful exogenous shocks coming from the rest of the global economy at key moments. I end with some speculations on these two themes. 


\subsection{Legal origins}

Influential work by Glaeser and Shleifer (2002) argues that an alternative and plausible "deep determinant" of economic success is "legal origin"-whether a country has a common law or civil code legal system. Empirically, legal origin is correlated with the colonizing power and, therefore, forms part of a broader argument that among all empires the British did more good than others by transmitting better institutions to the lands they conquered (Ferguson 2003). Common law obtains in the Anglosphere of rich settler countries such as the US, Canada, Australia, and New Zealand. The civil code prevails in continental European countries and their typically much poorer former colonies. In other former British colonies, say, the poorer regions of Africa and Asia, post-independence legal structures reflect a mixed system with common law elements and some civil code structures.

Once again, for those seeking deep determinants, Argentina offers an interesting, unique, and somewhat perverse case that is not easily classified. It is commonly noted that either system, common or civil, has a tendency to become somewhat mixed over time, as jurisprudence asserts its power in civil law, and as legislatures construct codes in common law systems. But Argentina was a very unusual case in that it was a mixed system from the start.

The early Argentine legal system was an outcome of a long political struggle from the period of independence (the failed Assembly of 1813 which tried to unite the provinces and establish government) until the country was finally unified (1859). Early efforts to write a constitution failed, not least given tension between centralists in Buenos Aires and opposing forces elsewhere. The other provinces, minus Buenos Aires province, promulgated the first Constitution in 1853, under the intellectual influence of Alberdi, with clear inspiration from the US, Swiss, and other early constitutions. The Argentine civil code only came later, in 1869, after unification, and was written by Vélez Sársfield.

How did these systems co-exist in practice and what economic effects did they have? Did one or other form take the upper hand at different times? Superficially, it appears that the common law features, especially judicial review and other powers, were often exercised in the nineteenth century. But in the twentieth century, the pendulum has swung more toward purely civil law operation, under both democracy and dictatorship - to such an extent that in the last decade the country has often called on foreign experts to assist in rebuilding some of the key functions of jurisprudence that have long lain dormant. Most legal origin evidence is crosssectional in nature, but here is an odd example of within-country time series variation. The coincidence of economic decline and the withering of Argentina's constitutional and common law traditions perhaps deserves further scrutiny for those interested in the applicability of the legal origin theory.

\subsection{Potential for trade}

Lastly, one important exogenous factor that is likely to have affected the path of institutions and policies in Argentina is the global economic environment, that is, 
the potential for international trade and capital flows. Prior to 1914, a growth strategy based on openness to capital inflows, frontier expansion, and the strong pursuit of comparative advantage based on primary exports carried the country to very high levels of income per capita income.

Was this strategy viable after 1914? Given the advent of the worldwide retreat to autarky that started then and lasts half a century, no. But what if the world economy had remained integrated? What would Argentina's counterfactual economic history have looked like? Could it have maintained high living standard and growth without being diverted onto the track of economic isolationism? No doubt the inevitable closing of the frontier in the early twentieth century Argentina implied a gradual structural shift from agriculture to manufacturing and services anyway (Di Tella and Zymelman 1967). But that shift would not have quickly overwhelmed Argentina's natural endowment-based comparative advantage. Argentina's structural shift was, therefore, rapidly accelerated by an autarkic economic environment - one that was at first imposed from abroad in the 1920s and 1930s, against the grain of domestic policy; but which was then reinforced by autarkic domestic policies which emerged in the 1940s and 1950s, and persisted over time to the present, long after the rest of the core economies of the world had dismantled barriers in trade and finance.

What explains this shift? And why might it have mattered more in the case of Argentina than in other developing countries of the time that followed the import substitution doctrine? Taking the second question first, I think the answer has something to do with the fact that Argentina had more to lose, on two levels. First, it had developed something like a modern economy, with adequately functioning market institutions, a hope of monetary stability (after 1891), and some semblance of democratic politics and rule of law as a foundation. Comparing Argentina to other recently industrialized emerging economies, we can say that none had advanced this far in 1914. Second, unlike many other such countries at the time, Argentina had more scope to achieve gains from trade-in both goods and capital markets. And these gains were at risk if the open trading environment broke down. Argentina had very high trade openness and relied on foreigners for almost half of the local capital stock and labor supply. For other countries with smaller trade shares and smaller financial inflows, the end of the first age of globalization entailed a fairly bothersome adjustment; for Argentina, it entailed a radical and painful reorientation, one delayed in the 1920s and 1930s by the unfulfilled hope that the pre-1914 liberal order might magically be restored.

As to the second question-why the shift?-we should perhaps consider the important interaction between economic openness, vested interests, and internal political economy dynamics. For example, in a different era, it has been argued that the "shock" of Atlantic trade expansion empowered mercantile/capitalist interests in the Anglo-Saxon Northwest corner of Europe, allowing this region to embrace economic and political reforms that enhanced openness and competition in the Early Modern period (Acemoglu et al. 2005). In Argentina, we may have seen something of the same path dependence driven by trade shocks, only in reverse: the shock of global trade contraction discrediting and weakening the old outward-looking order, and allowing new interests to arise with more autarkic goals. Significantly, again, 
Argentina's extreme comparative advantage would also play into this dynamic. Just as gains from trade would be larger in Argentina than in other countries, given the peculiar factor endowment, so for the same reasons the redistributive effects of autarky would be great too (for any trade distortion, when Harberger triangles are large, so too are the rectangles that measure redistribution of income, and thus power-see Rogowski 1989).

These observations fit with a broader theme in economic history which argues that economic and political competition are key complements via the forces unleashed in "open access" orders (North et al. 2009). Framed another way, one might say globalization and democracy go hand in hand, and, with empirical tests based on plausible instruments, this proposition holds up reasonably well (LópezCórdova and Meissner 2008).

Adverse external shocks, therefore, pose a danger to political institutions and, via path dependence, these events may have far-reaching consequences for economic policies. The case of Argentina is perhaps an extreme example: with the most to lose, the adverse global shocks in the mid-twentieth century were almost bound to cause the most damage here-a sobering thought since, as I write, the world tries to navigate its way out of another Great Depression.

Open Access This article is distributed under the terms of the Creative Commons Attribution 4.0 International License (http://creativecommons.org/licenses/by/4.0/), which permits unrestricted use, distribution, and reproduction in any medium, provided you give appropriate credit to the original author(s) and the source, provide a link to the Creative Commons license, and indicate if changes were made.

\section{References}

Acemoglu D, Johnson S, Robinson JA (2001) The colonial origins of comparative development: an empirical investigation. Am Econ Rev 91(5):1369-1401

Acemoglu D, Johnson S, Robinson JA (2005) The rise of Europe: Atlantic trade, institutional change, and economic growth. Am Econ Rev 95(3):546-579

Acharya RC and Keller W (2008) Estimating the productivity selection and technology spillover effects of imports. NBER Working Papers 14079

Arroyo Abad AL (2008) Inequality in Republican Latin America. Assessing the impact of factor endowments and trade. GPIH Working Papers No. 12. University of California, Davis

Barro RJ (2005) Rare events and the equity premium. NBER Working Papers 11310

Berlinski J (2003) International trade and commercial policy. In: Paolera G, Taylor AM (eds) A new economic history of Argentina. Cambridge University Press, Cambridge

$\mathrm{Bu}$ Y (2006) Fixed capital stock depreciation in developing countries: some evidence from firm level data. J Dev Stud 42(5):881-901

Caselli F, Feyrer JD (2007) The marginal product of capital. Quart J Econ 122(2):535-568

Coremberg AA (2003) Capital stock contribution to the productivity of the Argentine economy during The 1990's: a Hedonic Valuation Approach. Unpublished

Díaz-Alejandro CF (1970) Essays on the economic history of the Argentine Republic. Yale University Press, New Haven

Di Tella G, Zymelman M (1967) Las etapas del desarrollo económico argentino. Editorial Universitaria de Buenos Aires, Buenos Aires

Easterly W, Levine R (2001) What have we learned from a decade of empirical research on growth? it's not factor accumulation: stylized facts and growth models. World Bank Econ Rev 15(2):177-219

Easterly W, Levine R (2003) Tropics, germs, and crops: how endowments influence economic development. J Monetary Econ 50:3-39 
Engerman SL, Sokoloff KL (1997) Factor endowments, institutions, and differential paths of growth among new world economies: a view from economic historians of the United States. In: Haber S (ed) How Latin America fell behind. Stanford University Press, Stanford

Estevadeordal A, Taylor AM (2013) Is the Washington consensus dead? growth, openness, and the great liberalization, 1970s-2000s. Rev Econ Stat 95(5):1669-1690

Ferguson N (2003) Empire: the rise and demise of the British World order and the lessons for global power. Basic Books, New York

Gallup JL, Sachs JD, Mellinger AD (1999) Geography and economic development. Int Reg Sci Rev 22(2):179-232

Glaeser EL, Shleifer A (2002) Legal origins. Quart J Econ 117(4):1193-1229

Gollin D (2002) Getting income shares right. J Polit Econ 110(2):458-474

Gourinchas P-O, Jeanne O (2006) The Elusive Gains from international financial integration. Rev Econ Stud 73(3):715-741

Hall RE, Jones CI (1999) Why do some countries produce so much more output per worker than others? Quart J Econ 114(1):83-116

Hsieh C-T, Klenow PJ (2009) Misallocation and manufacturing TFP in China and India. Quart J Econ 124(4):1403-1448

Kydland F, Zarazaga CEJM (2002) Argentina's recovery and excess capital shallowing of the 1990s. Estudios de Economia 29:35-45

López-Córdova JE, Meissner CM (2008) The impact of international trade on democracy: a long-run perspective. World Polit 60(4):539-575

Maddison A (2007) Historical statistics for the world economy, 1-2003 AD. http://www.ggdc.net. Accessed 2009

Mehra R, Prescott EC (1985) The equity premium: a puzzle. J Monetary Econ 15(2):145-161

North DC, Wallis JJ, Weingast BR (2009) Violence and social orders: a conceptual framework for interpreting recorded human history. Cambridge University Press, New York

Reinhart CM, Rogoff KS (2004) Serial default and the "Paradox" of rich-to-poor capital flows. Am Econ Rev 94(2):53-58

Rietz TA (1988) The equity risk premium: a solution. J Monetary Econ 22(1):117-131

Rodrik D, Subramanian A, Trebbi F (2004) Institutions rule: the primacy of institutions over geography and integration in economic development. J Econ Growth 9(2):131-165

Rogowski R (1989) Commerce and coalitions: how trade affects domestic political alignments. Princeton University Press, Princeton

Tanzi V, Davoodi HR (1997) Corruption, public investment, and growth. IMF Working Papers 97/139, International Monetary Fund 